\title{
Relative Effectiveness of Methane (Biogas) Production from Dry Grass Soaked with Vegetable Waste, Poultry Waste and Cow Dung
}

\author{
RAJESH S, PREMKUMAR R and JAYADEVI NEETHIPATHI* \\ 123.Department of Civil Engineering, Kalasalingam Academy of Research And Education, \\ Krishnankovil, Tamilnadu, India. \\ *Corresponding author E-mail: jayakardevi@gmail.com \\ http://dx.doi.org/10.13005/ojc/350232
}

(Received: January 31, 2019; Accepted: April 06, 2019)

\begin{abstract}
A conceit was based on bountifully randomised deigns with several numbers of proportions (1:1:1:1, 1.5:0.5:1:1, 2:0.5:0.5:1, 0.5:1.5:1:1). According to the antecedent contemplation, different parameters and eternal pouring of waste grieved the biogas origination and increases the substantial exhaustion every day. This model is to improve the excess amount of biogas mass with controlled $\mathrm{pH}$ condition and permanent dumping of waste to digester to shun the wastes in regular days. The different compounds of waste are imbrue with dry grass and agitate with cow dung, poultry waste and vegetable waste. Biogas production bows with the help of anaerobic bacteria with the existence of mesophilic temperature of $32^{\circ}$. Biogas augmentation starts on 144 to 125 hours, which it reaches uttermost range of $78.9 \mathrm{~L}$ to $79.35 \mathrm{~L}$ and the judicious range of $49 \mathrm{~L}$ to $50 \mathrm{~L}$ gas occur in 144 to 288 hours. Among the apparent ratio 2:0.5:0.5:1 gives the ultimate yield of bio gas.
\end{abstract}

Keywords: Cow Dung, Poultry Waste, Vegetable Waste, Dry Grass, Bio gas, Bio Digester.

\section{INTRODUCTION}

The miniature of this paper to dwindle the solid waste is cesspool to the ground or land fill. Dumping of sturdy waste are cow dung, poultry waste, vegetables waste, fruit waste, sludge etc. To avoid the renewable solid misuse dumped into the ground, the biogas model prepared is regulated. Through this model the waste such as cow dung, poultry waste with dry grass, and the vegetable waste are dumped into the bio digester, To get the source of energy i.e. biogas through anaerobic condition. Mostly the biogas are groomed from animal feeds such as cow dung, poultry waste, dog waste, rabbit waste etc. Typically animal wastes have the high methane content when it compare to vegetable waste, plant waste etc. From the past decade the cow dung cake are used for the cooking purpose because the highly presence of methane content present in it. (Salunkhe et al., 2009) stated that bio gas prepared from the Liquid Composite Waste from Corn Glucose Factory, The bio methanation potential of liquid composite waste from a corn glucose factory with the cow dung. (Zhen Feng et al., 2017) describes that the bio gas are prepared from the rice straw and the cow manure with the different ratio under the

This is an Open Access article licensed under a Creative Commons license: Attribution 4.0 International (CC- BY). Published by Oriental Scientific Publishing Company @ 2018 
Mesophilic $\left(37^{\circ} \mathrm{C}\right)$ anaerobic co-digestions of rice straw and cow manure were carried out based on different ratios $(0: 1,1: 2,1: 1,2: 1$ and 1:0). (A. Kumar et al., 2016) stated that the biogas are generated from the wet animal waste (cow dung) and vegetable waste under the anaerobic digestion, An alternative method of obtaining gaseous fuel is through the anaerobic fermentation of wet livestock(animal and vegetable) wastes to produce biogas which is a mixture of methane $(45-75 \%)$ and carbon dioxide. (Milad Ebrahimi et al., 2017) describes the bio gas yield from the treated organic waste water. Methane gas production from treating high-strength synthetic. (Brune et al., 2009) also describes about algae biomass with the replacement of the animal feed. (Huoqing Ge et al., 2013) stated that the biogases are prepared from the chemical reagent used in the sewer to reduce the sulphite content in the digester to get the maximum methane content. (Wang Yao et al., 2016) stated that bio gas that are composed from the food waste with the presence of certain chemicals to increases the methane and to decline the other compositions. Among the uttermost reviews the biogas preparation through the animal feeds and the solid decomposable waste such as vegetable waste and dry grass are carry over in this project. The objective of this study is to analyse, the quantity of the biogas from animal waste (i.e. cow dung, poultry waste) and biodegradable vegetable waste which was soaked with dry grass with the optimum temperature. And the need of the project to enact the ultimate amount of biogas formulation in short period of time.

\section{MATERIALS AND METHODS}

\section{Experimental design}

This paper is based on completely randomised design with several number of ratios 1:1:1:1, 1.5:0.5:1:1, 2:0.5:0.5:1, 0.5:1.5:1:1 of cow dung, poultry waste and vegetables waste are soaked with dry grass with the same quantity of water. For $1: 1: 1: 1$ ratio, $3.7 \mathrm{~kg}$ of cow dung, $3.7 \mathrm{~kg}$ of poultry waste + dry grass and $3.7 \mathrm{~kg}$ of vegetable waste with 3.7 litres of water to the $20 \mathrm{~L}$ biodigester belongs to 5 litres gap in the top of the digester. And the simultaneous process is followed in 1.5:0.5:1:1, 2:0.5:0.5:1and 0.5:1.5:1:1 etc. The below Table 1 represents the different feeding ratio into the bio digester.

Table 1: Quantity of ratio is feeding into biodigester

\begin{tabular}{ccccccccc}
\hline S.no & $S W$ & $1: 1: 1: 1$ & $S W$ & $1.5: 0.5: 1: 1$ & $S W$ & $2: 0.5: 1: 1$ & $S W$ & $0.5: 1.5: 1: 1$ \\
\hline 1. & $\mathrm{CdQ}$ & $3.7 \mathrm{~kg}$ & $\mathrm{CdQ}$ & $3.7 \mathrm{~kg}$ & $\mathrm{Cd}+\mathrm{dGq}$ & $5.4 \mathrm{~kg}$ & $\mathrm{CdQ}$ & $1.85 \mathrm{~kg}$ \\
2. & $\mathrm{Pw}+\mathrm{dGq}$ & $3.7 \mathrm{~kg}$ & $\mathrm{PW}+\mathrm{dGq}$ & $3.7 \mathrm{~kg}$ & $\mathrm{Pwq}$ & $1.87 \mathrm{~kg}$ & $\mathrm{PW}+\mathrm{dGq}$ & $5.55 \mathrm{~kg}$ \\
3. & $\mathrm{Vwq}$ & $3.7 \mathrm{~kg}$ & $\mathrm{Vwq}+\mathrm{dGq}$ & $3.7 \mathrm{~kg}$ & $\mathrm{Vwq}$ & $1.87 \mathrm{~kg}$ & $\mathrm{Vwq}$ & $3.7 \mathrm{~kg}$ \\
4. & $\mathrm{Wq}$ & $3.7 \mathrm{~L}$ & $\mathrm{Wq}$ & $3.7 \mathrm{~L}$ & $\mathrm{Wq}$ & $3.7 \mathrm{~L}$ & $\mathrm{Wq}$ & $3.7 \mathrm{~L}$ \\
& Total & $15 \mathrm{~L}$ & Total & $15 \mathrm{~L}$ & Total & $15 \mathrm{~L}$ & Total & $15 \mathrm{~L}$ \\
\hline
\end{tabular}

SW- solid waste,

$\mathrm{Cd}+\mathrm{dGq}-$ Cow dung +dry grass quantity,

$P w+d G q-$ poultry waste+ dry grass quantity,

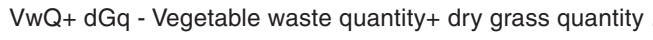

\section{Slurry mixing tank}

It is a pre-mixing chamber where the disparate component of the raw materials are mixed with the water. Blending of waste in the measuring jar

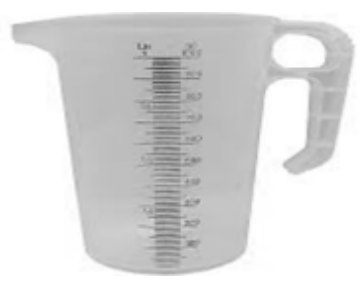

Fig. 1. Slurry mixing jar
CdQ- Cow dung quantity,

Pw-poultry waste,

VwQ- Vegetable waste quantity,

(Fig.1). Where the uniform weave of slurry is fodder to the digester (Fig. 2). A $1000 \mathrm{ml}$ of jar with the tray is used for adulterate the waste are feed into the bio digester under the alternate ratios.

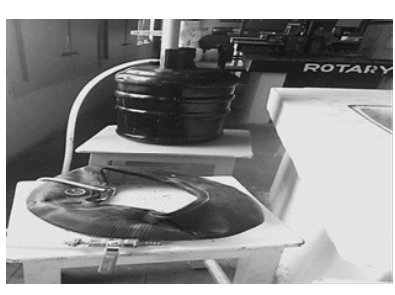

Fig. 2. Model bio digester 


\section{Materials for bio gas production}

It is a prevailed proceeding for employing cow dung and poultry waste, wooden pieces, leaves, rice husk, paddy waste etc, to be dried and then used directly as a solid fuel for cooking. Nowadays, one of the most important scenario in the world is uncontrolled decomposition of solid waste causes the environmental pollution. Increase of carbon-di-oxide emission because of using fossil energy sources cause global warming. And rotten Vegetables solid waste (such as lady's finger, brinjal, potatoes, beetroot, tomatoes, cabbage, bitter gourd etc.) are produced in larger quantities in market and which constitute as a source of nuisance in municipal landfills because of their high biodegradability (Viturti et al.,1989). Hence the parameters are studied for each waste such as $\mathrm{pH}$, chemical oxygen demand (cod), total dissolved solids, electrical conductivity and temperature are studied. Biogas process can help to reduce $\mathrm{CO}_{2}$ emissions, also useful in reducing the non-renewable energy resources such as fossil energy coal, petroleum, LPG gas etc. (Aremu and Agarry et al., 2013). Due to the increase in the price of petroleum and its demand, the environmental burden about pollution from burning gases, biogas is becoming ultimate concern in now a days. Anaerobic digestion has been found a very good method to reduce organic matter and odours, destroy pathogens and produce energy (methane) in the presences of anaerobic bacteria such as amino bacterium, bacillus cereus etc. Furthermore, anaerobic digestion is a good option to reduce mass volume of animal (cow dung waste and poultry waste) and vegetable wastes in the present environment. Anaerobic digestion is the processing in the absence of oxygen takes place. (J. Martin-Pascual et al., 2017) describes that Optimization of the Acid Stage of a Two-Stage Anaerobic Digestion Process efficiency of a two-stage mesophilic anaerobic sludge digestion process was compared with a conventional process to treat urban sludge in relation to the hydraulic retention time (HRT) of the acid stage. (S. Jayanthi, et al., 2009) describes about the pilot scale plant study of bio digester. Pilot plant is the single stage Bio Digester (500 litter model set up digester) performance was monitored by measuring daily $\mathrm{pH}$ and gas production. So, Anaerobic digestion has become the most widespread stabilization process in municipal waste water treatment plant (Arnaiz et al., 2006). Materials mandatory to brace bio digester are $20 \mathrm{~L}$ water bottle, $3 / 4$ length of PVC pipe i.e. , one pipe to the inlet and other pipe to the outlet, the tyre tube, gas valve, hose and the top closed valve. The wastes are swarm to the bio digester from the top of the valve and the gases are poised in the auto tube.

\section{Biogas formation \\ Biogas formulation by 4 phases}

1. Hydrolysis (broking of larger compounds into simpler compounds).

2. Acidogenesis (presences of fermentative bacteria).

3. Actogenesis (acetate producing bacteria to produce hydrogen and carbon di oxide).

4. Methanogenesis (methane and carbon di oxide is out turned).

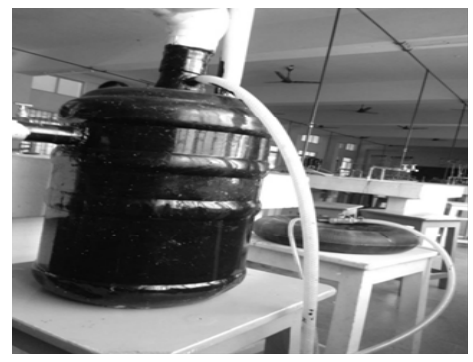

Fig. 3. After gas formation in tyre tube

The above Fig. 3 illustrates the gas formation in the bio digester. Gas gets starts on the second day itself, and the gas formulation is in the existence of anaerobic bacteria are concealed by the controlled $\mathrm{pH}$ condition with the sustain temperature.

\section{Yield of biogas ratio calculation}

Area and volume calculation for bio digester

Volume of cylinder $=\pi \mathrm{r}^{2} \mathrm{~h}$

Height of can $=30 \mathrm{~cm}^{3}$, Radius $=12.5 \mathrm{~cm}^{3}$

So, volume $=\pi \times(12.5)^{2} \times 30=14718.75 \mathrm{~cm}^{3}$

$\mathrm{V}=0.0147187 \mathrm{~m}^{3} \mathrm{OR} \sim 15 \mathrm{~L}$

\section{Required Area}

$\mathrm{V}=\mathrm{A} \times \mathrm{H}, \mathrm{A}=\mathrm{V} / \mathrm{H}$

$A=0.01471 / 0.41$

$A=0.035 \mathrm{~m}^{2}$

So ,the required area is $0.035 \mathrm{~m}^{2}$ and the pouring of cow dung, poultry waste soaked with dry grass and vegetable waste in ratio of $1: 1: 1: 1$, 1.5:0.5:1, 2:0.5:0.5:1 and 0.5:1.5:1:1 up to volume of $15 \mathrm{~L}$ in digester. 
Volume of gas design for per hour

Volume of hollow circular tube $=\pi r^{2} \mathrm{~h}$

Height or length of tube $=91.15 \mathrm{~cm}$

Diameter of gas volume in tube $=1.624$

$r=1.624 / 2$

$r=0.812$

$v=\pi \times(0.812)^{2} \times 91.15$

$\mathrm{V}=188.76 \mathrm{~cm}^{3} \sim 189 \mathrm{~cm}^{3}$

$\mathrm{v}=0.000189 \mathrm{~m}^{3} / 0.189 \mathrm{~L}$.

The above values are corresponding to the below table values (i.e., result and discussion values) to calculate the daily volume of biogas in bio digester.

\section{Parameters studied}

The below Table 2 represents the virtue of substantial misuse molder criterion are commencing $\mathrm{pH}$ for the three solid waste is below the 7 salinity of the analogous solid waste is low so the obtainable anaerobic bacterial growth surges in the bio digester. COD is the chemical oxygen demand which is used to measure the oxygen demand by the using of chemicals. The initial range and the final range of the cod is $450-850 \mathrm{mg} / \mathrm{l}$ so in this range the bacterial growth is better to outturn the bio gas .Electrical conductivity is in the range of 1.0-1.9 which is used to inlays the exposure of the solid waste to curtail the salinity. The initial and the final range of total dissolved solids are $0.15-0.6 \mathrm{ppt}$ is drawn pared, it will escalate the bio gas yield. Mesophilic range of temperature $\left(25-45^{\circ} \mathrm{C}\right)$ worn to increases the bacterial growth.

Table: 2 parameters studied in solid decomposable waste

\begin{tabular}{|c|c|c|c|c|c|c|c|c|}
\hline S. no & Instrument & Cow dung & Poultry waste & Vegetable waste & $\begin{array}{l}\text { Testing } \\
\text { result of } \\
1: 1: 1: 1\end{array}$ & $\begin{array}{c}\text { Testing } \\
\text { result of } \\
1.5: 0.5: 1: 1\end{array}$ & $\begin{array}{c}\text { Testing } \\
\text { result of } \\
2: 0.5: 0.5: 1\end{array}$ & $\begin{array}{c}\text { Testing } \\
\text { Result of } \\
0.5: 1.5: 1: 1\end{array}$ \\
\hline 1 & $\mathrm{pH}$ & 6.52 & 6.29 & 6.01 & 6.7 & 6.5 & 6.1 & 6.1 \\
\hline 2 & COD (mg/l) & 450 & 470 & 100 & 850 & 720 & 680 & 700 \\
\hline 3 & $\mathrm{EC}(\mu \mathrm{s} / \mathrm{cm})$ & 1.032 & 1.15 & 1.016 & 1.8 & 1.6 & 1 & 1.4 \\
\hline 4 & TDS (ppt) & 0.507 & 0.567 & 0.546 & 0.15 & 0.11 & 0.099 & 0.12 \\
\hline 5 & Temperature $\left({ }^{\circ} \mathrm{c}\right)$ & 30 & 29.9 & 30.3 & 32 & 32 & 32.5 & 32 \\
\hline
\end{tabular}

\section{RESULT AND DISCUSSION}

Daily agglomeration of biogas under the contrasting duration of time such as (9am-10am, $10 \mathrm{am}-11 \mathrm{am}, 11 \mathrm{am}-12 \mathrm{pm}, 12 \mathrm{pm}-1 \mathrm{pm}, 1 \mathrm{pm}-2 \mathrm{pm}$, $2 p m-3 p m, 3 p m-4 p m, 4 p m-9 a m)$. The beneath corresponding values (i.e., Table 3 ) are based on the daily collection of biogas in peculiar duration Ex $(0.189+0.0012+1.53+1.72+1.97+3.4+4.6+17$. $3 \mathrm{~L}=31.9 \mathrm{~L})$. The abundance of bio gas produced from the proportion of cow dung, poultry waste, dry grass and vegetable waste are formed with in fifth to sixth days. The below Table 3 represents the total capacity of biogas. Hence the amount of gas get increased and decreased spontaneously in next following days due to the temperature changes and the other factors such as $\mathrm{pH}, \mathrm{COD}$, TDS etc. Hence the gas production suddenly escalates the peak value of $72 \mathrm{~L} /$ day to $79.3 \mathrm{~L} /$ day and get curtail to $45-49$ $L$ day was underneath by the certain ratios of $1: 1: 1: 1$, 1.5:0.5:1:1, 2:0.5:0.5:1 and 0.5:1.5:1:1. And the bio gas formulation is in the presences of the anaerobic microorganism with the truancy of sunlight takes places. Avoid the penetration of sunlight to gain the growth of microorganism to degrade the waste in the absence of sunlight to get the maximum amount of methane and the minimum amount of carbon di-oxide.

Table 3: Total quantity of biogas required in the corresponding ratio

\begin{tabular}{|c|c|c|c|c|}
\hline Number of days & Total quantity $(1: 1: 1: 1)$ & Total quantity (1:5:0.5:1:1) & Total quantity (2:0.5:0.5:1) & Total quantity $(0.5: 1.5: 1: 1)$ \\
\hline 1 & $0.0354 \mathrm{~m}^{3} / 35.4 \mathrm{~L}$ & $0.0368 \mathrm{~m}^{3} / 36.8 \mathrm{~L}$ & $0.04008 \mathrm{~m}^{3} / 40.08 \mathrm{~L}$ & $0.0324 \mathrm{~m}^{3} / 32.4 \mathrm{~L}$ \\
\hline 2 & $0.0319 \mathrm{~m}^{3} / 31.9 \mathrm{~L}$ & $0.0361 \mathrm{~m}^{3} / 36.1 \mathrm{~L}$ & $0.03806 \mathrm{~m}^{3} / 38.06 \mathrm{~L}$ & $0.0296 \mathrm{~m}^{3} / 29.6 \mathrm{~L}$ \\
\hline 3 & $0.0535 \mathrm{~m}^{3} / 53.5 \mathrm{~L}$ & $0.0466 \mathrm{~m}^{3} / 46.6 \mathrm{~L}$ & $0.05547 \mathrm{~m}^{3} / 55.47 \mathrm{~L}$ & $0.0498 \mathrm{~m}^{3} / 49.8 \mathrm{~L}$ \\
\hline 4 & $0.0682 \mathrm{~m}^{3} / 68.2 \mathrm{~L}$ & $0.0742 \mathrm{~m}^{3} / 74.2 \mathrm{~L}$ & $0.07738 \mathrm{~m}^{3} / 77.38 \mathrm{~L}$ & $0.0652 \mathrm{~m}^{3} / 65.2 \mathrm{~L}$ \\
\hline 5 & $0.0789 \mathrm{~m}^{3} / 78.9 \mathrm{~L}$ & $0.0792 \mathrm{~m}^{3} / 79.2 \mathrm{~L}$ & $0.07939 \mathrm{~m}^{3} / 79.39 \mathrm{~L}$ & $0.0653 \mathrm{~m}^{3} / 65.3 \mathrm{~L}$ \\
\hline 6 & $0.0491 \mathrm{~m}^{3} / 49.1 \mathrm{~L}$ & $0.0530 \mathrm{~m}^{3} / 53.0 \mathrm{~L}$ & $0.05165 \mathrm{~m}^{3} / 51.65 \mathrm{~L}$ & $0.0653 \mathrm{~m}^{3} / 65.3 \mathrm{~L}$ \\
\hline 7 & $0.0493 m^{3} / 49.3 \mathrm{~L}$ & $0.0507 \mathrm{~m}^{3} / 50.7 \mathrm{~L}$ & $0.05165 \mathrm{~m}^{3} / 51.65 \mathrm{~L}$ & $0.0401 \mathrm{~m}^{3} / 40.1 \mathrm{~L}$ \\
\hline 8 & $0.0493 m^{3} / 49.3 \mathrm{~L}$ & $0.0506 \mathrm{~m}^{3} / 50.6 \mathrm{~L}$ & $0.05085 \mathrm{~m}^{3} / 50.85 \mathrm{~L}$ & $0.0401 \mathrm{~m}^{3} / 40.1 \mathrm{~L}$ \\
\hline
\end{tabular}


The below Fig $(4,5,6,7)$ which corresponds to the total pile of the biogas required per day and also discuss about the maximum amount of the biogas required in the different stages in different ratio. In this graphical representation the maximal chunk of

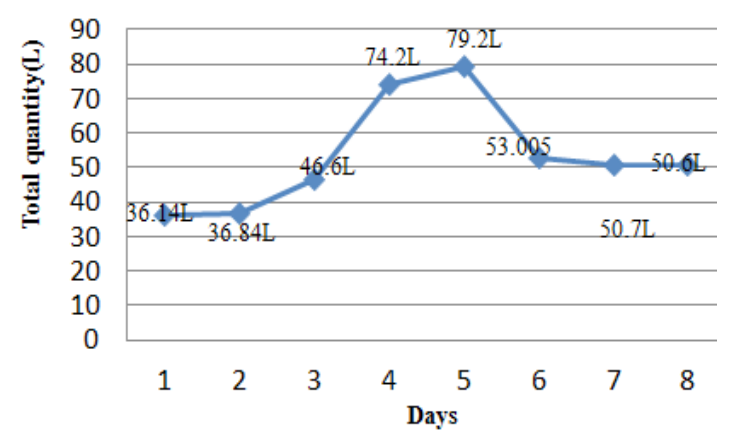

Fig. 4. Total quantity $(1: 1: 1: 1)$

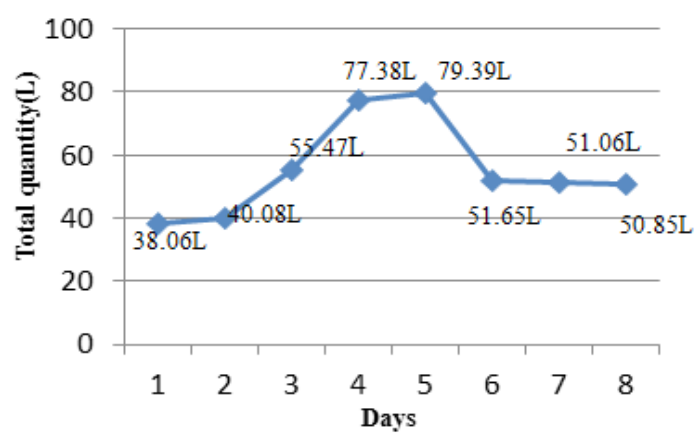

Fig. 6. Total quantity (2:0.5:0.5:1)

\section{CONCLUSION}

The preceding studies are to mend my ratios by proliferating the maximum amount of bio gas in short period of time and also reducing the condensing wastes. 2: 0.5: 0.5: 1 which gives the maximum amount of biogas, when correlate to the distinct ratios $(1: 1: 1: 1,1.5: 0.5: 1: 1$ and 0.5 : 1.5: 1: 1). And the crescent amount of the cow dung increases the bio gas yield. From the 1:1:1:1, $1.5: 0.5: 1: 1,2: 0.5: 0.5: 1$ and $0.5: 1.5: 1: 1$ ratios that gives the maximum yield in 96 to 120 hours and get continuously decreased in 144 hour. The rebate of the poultry waste with rising the amount of cow dung and vegetable waste with dry grass which flourishing the bio gas. And the transitory pouring waste to bio digester gives the stable amount of biogas till the 960 to 1080 hours and after that another feeding is required. The stable amount of biogas is 49-50L/ day and the maximum amount is $75-80 \mathrm{~L} /$ day. Hence later the evolution of the gas with respective solid the biogas yields in the 2:0.5:0.5:1 ratio. Hence this ratio gives transcend termination when correlate to the auxiliary debate while using the cow dung, poultry waste with the dry grass and the vegetable waste which decline the carbon di oxide and rising the biogas.

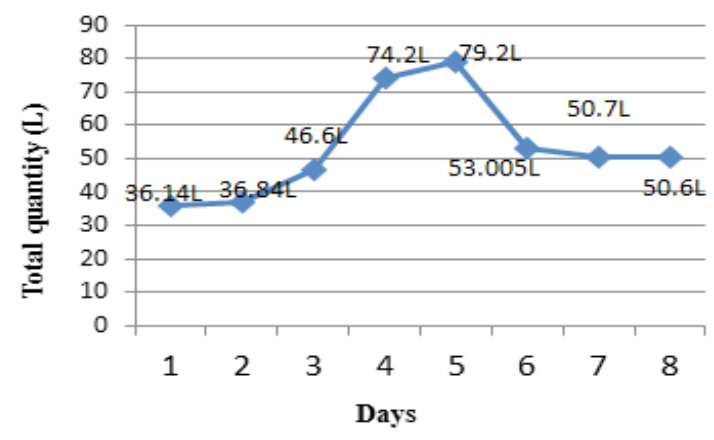

Fig. 5. Total quantity (1.5:0.5:1:1)

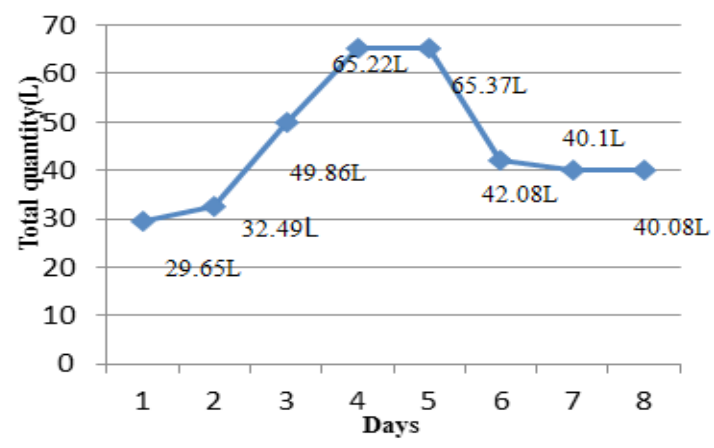

Fig. 7. Total quantity $(0.5: 1.5: 1: 1)$

waste in the bio digester is used as the bio fertilizers to replacement of chemical fertilizers.

\section{ACKNOWLEDGEMENT}

I would like to thank the vice chancellor of kalasalingam Academy of Research and Education acquiesce me do to this project work. I utter my deep sense of requital and genuine thanks to my HOD (Dr. C. Ramesh babu) for providing all tentative ease to replete my project successfully in empirical facilities of school of environment and construction technology. Also like to thank my project pioneer (S.Rajesh and R.Premkumar) for their worthwhile guidance and patron to accomplish my project work.

\section{CONFLICT OF INTEREST}

There is no strife among us while doing the project work. The solid extravagance (cow dung and poultry waste) are corpus in nearer area And the vegetable waste are extracts in nearer hotels. 


\section{REFERENCES}

1. Achouri, O.; Panico, A.; Bencheikh-Lehocine, M.; Derbal , K. ; Pirozzi, F.; Effect of Chemical Coagulation Pretreatment on Anaerobic digestion of tannery waste water. J. Environ. Eng., 2017, 143, 9.

2. Carucci ,G.; Carrasco,F.;Trifoni,K.; Majone, M. ; Beccari ,M.; Anaerobic Digestion of Food Industry Wastes. J.Environ. Eng., 2005, 131, 7.

3. Dingnan ,Lu .; Xiaoqi Jackie Zhang .; Biogas Production from Anaerobic Co digestion of Microalgae and Septic Sludge. J. Environ. Eng., 2016 , 142, 10.

4. Brune, D.E.; Lundquist, T.J.; Benemann, J.R.; Micro algal Biomass for Greenhouse Gas Reductions Potential for Replacement of Fossil Fuels and Animal Feeds. J. Environ. Eng., 2009, 11, 1136-1144.

5. Salunkhe, A.K.; Deshmukh, A.M.; Studies on Biomethanation Potential of Liquid Composite Waste from Corn Glucose Factory. Nature Environment and Pollution Technology., 2009, 8, 489-495.

6. Martin-Pascual, J.; Rueda-Perez, J. J; Jover, M.; Hontoria, E.; Poyatos , J.M; Optimization of the Acid Stage of 2 Stage Anaerobic Digestion Process to Treat Wastewater Sludge. J. Environ. Eng., 2017, 143, 9.

7. Ramesh,S.T.; Jayanthi, S.; Gandhimathi ,R.; Pilot Plant Study on Combined Treatment of Kitchen Refuse and Domestic Sewage By
Anaerobic Digestion. Nature Environment and Pollution Technology., 2009, 8, 157-160.

8. Huoqing Ge; Lishan Zhang; Damien, J.; Batstone; Jurg Keller; Zhiguo Yuan; Impact of Iron Salt Dosage to Sewers on Downstream Anaerobic Sludge Digesters- Sulfide Control and Methane Production. J. Environ. Eng., 2013, 139, 4.

9. Zhen Feng; Wang Yao; Sun Yongming; Kong Xiaoying; Yuan Zhenhong; Zhuang Xinshu; Effect of Feeding Ratio on Anaerobic Co-Digestion of Rice Straw and Cow Manure. Nature Environment and Pollution Technology., 2017, 16 (3), 837-842.

10. Kumar, A.;Rasappan,K.; Santhosh ,P.; Synthesis of Biogas as a Renewable Energy from Organic Waste Mixture by Anaerobic Fermentation. Nature Environment and Pollution Technology., 2016, 15 ( 2), 437-442

11. Wang Yao; Sun Yongming; Yuan Zhenhong; Li Lianhua; Zhuang Xinshu ; Effect of Trace Elements Supplement on Anaerobic Fermentation of Food Waste. Nature Environment and Pollution Technology., 2016, 15( 2), 747-753.

12. Milad Ebrahimi ; Hamidreza Kazemi ; Mirbagheri,S.A ; Thomas ,D.;Rockaway; Integrated Approach to Treatment of HighStrength Organic Wastewater by Using Anaerobic Biological Contactor. J. Environ. Eng., 2017, 144, 2. 